\title{
Inferring The Cost Of Equity: Does The CAPM Consistently Outperform The Income And Multiples Valuation Models?
}

Vusani Moyo, University of Venda, South Africa

Fidelis Mache, University of Venda, South Africa

\begin{abstract}
A number of surveys reveal that a large number of analysts, valuation experts, investors, chief financial officers and finance academics employ the capital asset pricing model (CAPM) of Sharpe (1962) and Lintner (1965) to estimate the cost of equity. There are, however, a number of alternative valuation models that can be used to infer the cost of equity. These alternative equity valuation models include the constant growth dividend discount, the earnings and book market multiples, the residual income and the Ohlson and Juettner-Nauroth (2005) abnormal earnings growth (AEG) models. Using four mature retail firms listed on the Johannesburg Stock Exchange, this paper tested for the equivalence of these models to the CAPM in estimating the cost of equity. The study found that the variants of the constant growth dividend discount and the AEG models give similar estimates which are closer to those of the CAPM. The variants of the price-to-earnings market multiples, price-to-book market multiples, and residual income models all yield estimates that are higher than those of the CAPM. Finally, the estimates seem to be affected by the stability of the firm's earnings and financial position.
\end{abstract}

Keywords: Capital Asset Pricing Model; Residual Income; Ohlson and Juettner-Nauroth (2005) Abnormal Earnings Growth; Price-To-Earnings Market Multiples; Price-To-Book Value Multiples

\section{INTRODUCTION}

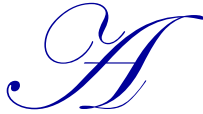

lthough Dempsey $(2013$, p. 7) labels it a failed revolutionary idea in corporate finance, the William Sharpe (1962) and John Lintner's (1965) capital asset pricing model (CAPM) still remains a leading model that analysts, valuation experts, investors, chief financial officers and finance academics use to calculate the cost of equity. Past surveys reveal that this model is more popular than its peers which include the FamaFrench (1996) three factor model, the arbitrage pricing model and the constant growth dividend discount model. For example, a survey done by Bruner, Eads, Harris, and Higgins (1998) found that $85 \%$ of the best managed United States of America companies used the CAPM in estimating the cost of equity. A CFO survey conducted by Graham and Harvey $(2001$, p. 210$)$ revealed that $73.5 \%$ of the surveyed CFOs use the CAPM in calculating the cost of equity. Welch (2008) found that 75\% of finance professors recommend the use of the William Sharpe (1962) and John Lintner (1965) CAPM in calculating the cost of equity. Lastly, the Bancel and Mittoo (2014) survey of 365 European finance experts revealed that $80 \%$ of them use the CAPM to estimate the cost of equity.

From the results of these surveys, the questions that may be asked are: why is the CAPM more preferred than the other models used to estimate the cost of equity? Is it that these models yield poor estimates of the cost of equity than the CAPM or this is simply a question of practioner preference? This paper tested this hypothesis by comparing the estimates of the cost of equity for four mature retail firms listed on the Johannesburg Stock Exchange (JSE) calculated using the CAPM and the variants of the constant growth dividend discount, the earnings and book market multiples, the residual income and the abnormal earnings growth equity valuation models.

The study found persistent heterogeneity in cost of capital across all models. In all cases, the estimates of the cost of equity obtained using the variants of all models are higher than the CAPM estimates. In using the firm's sustainable growth rate as a proxy for growth, the constant growth dividend discount and the Ohlson and Juettner-Nauroth (2005) 
abnormal earnings growth (AEG) yield similar estimates which are closer to those of the CAPM. The estimates of the price-to-earnings market multiples, residual income model and the price-to-book market multiples variants are higher than the estimates obtained using the CAPM, the dividend discount and the OJ (2005) AEG models. The variance of the estimates is also affected by the company's data.

The rest of the paper is structured as follows. Section 2 discusses the CAPM. The variants of the dividend discount, the market multiples, the residual income and the AEG models are discussed in Section 3. Section 4 discusses the application of the models and Section 5 presents the estimation results. Section 6 concludes the study.

\section{INFERRING THE COST OF EQUITY USING THE CAPITAL ASSET PRICING MODEL}

The Sharpe (1964) and Lintner (1965) capital asset pricing model (CAPM) states that the expected return from an asset is the sum of the return from the risk-free asset and the "asset's market risk premium". The asset's market risk premium is the "equity market risk premium" multiplied by the asset's systematic risk index. The equity market risk premium (EMRP) is simply the difference between the expected overall market return and the return from a risk-free security. According to Dempsey (2013, p. 7), the model asserts that equity assets are priced commensurate with a trade-off between undiversifiable risk and expectations of return. This leading model, which was derived from the works of William Sharpe (1962), John Lintner (1965), Jack Treynor (1962) and Jan Mossin (1966) is formally stated as:

$$
E\left(r_{i}\right)=k_{e}=r_{f}+\beta_{i, m}\left[E\left(r_{m}\right)-E\left(r_{f}\right)\right]
$$

Where $E\left(r_{i}\right)$ is the expected return from stock $k_{i}$ which is the cost of equity to the firm, $k_{e}, r_{f}$ is the risk-free rate whose proxy is normally the yield of either a 1-year or 10-year government debt instrument (Treasury Bill), $\beta_{i}$ measures the systematic (non-diversifiable) risk of $s$ ock $_{i}$ relative to the market portfolio and $E\left(r_{m}\right)$ is the expected return from the market portfolio. The CAPM can also be expressed as:

$$
k_{e}=r_{f}+\beta_{i} \times M R P
$$

or,

$$
k_{e}=r_{f}+E R P
$$

Where:

$$
\begin{aligned}
& \beta_{i}=\text { equity beta } \\
& \left(R_{m}-R_{f}\right)=\text { market risk premium }(M R P) \\
& \beta_{i} \times\left(R_{m}-R_{f}\right)=\text { equity risk premium }(E R P)
\end{aligned}
$$

As discussed in the introduction, a number of surveys including those of Bruner et al. (1998), Graham and Harvey (2001, p. 210), Welch (2008) and Bancel and Mittoo (2014) reveal that this is the most widely used model in estimating the cost of equity. The alternatives to this risk-based model are the dividend discount, equity multiples, residual income and the AEG models. These models are discussed next.

\section{INFERRING THE COST OF EQUITY USING THE ALTERNATIVES EQUITY VALUATION MODELS}

The cost of equity can also be inferred from the equity income-based and market multiples valuation models. These models which include the constant growth dividend discount, the earnings and book market multiples, the residual income and the AEG models, use data from the financial statements of the firm as well as the current share price. Depending on the model, the variables used include the dividend per share, the earnings per share, return on equity as well as book value per share. All these models require an estimate of growth rate which is normally estimated as the 
geometric average growth over the past 5 years. For example, the dividend growth rate can be estimated as the firm's historical dividend geometric mean. This is estimated as follows.

\subsection{Estimating Growth Rates}

If dividend per shares (DPS) grows at a constant rate, then next year's dividend, $D P S_{1}$, can be estimated from last year's dividend per share, $D P S_{0}$, using the model:

$$
D P S_{1}=D P S_{0} \times(1+g)
$$

The dividend constant growth rate can then be estimated using:

$$
g=\frac{D P S_{1}}{D P S_{0}}-1
$$

In equity valuation, the growth rate is normally estimated as the geometric mean of the past 5-year dividends. Thus, in considering a 5-year growth period, the geometric mean growth in dividends is calculated as:

$$
(1+g)=\left(\frac{D P S_{5}}{D P S_{1}}\right)^{1 / 4} \Rightarrow g=\left(\frac{D P S_{5}}{D P S_{1}}\right)^{1 / 4}-1
$$

This can generally be stated as:

$$
g=\left(\frac{D P S_{0}}{D P S_{-n}}\right)^{1 / n}-1 \equiv\left[\left(\frac{\text { Last dividend }}{\text { starting period dividend }}\right)^{1 / \text { no.of years }}-1\right]
$$

The main problem with the dividend growth rate calculated this way is that it assumes that dividends grew at a constant rate over the last five years. This is however not normally the case as divided growth rate can change from year-toyear thus the constant growth assumption therefore rarely holds. The most suitable proxy of the firm's optimum growth rate is its sustainable growth rate (Brealey, Myers \& Allen, 2008, p. 808). The sustainable growth rate is the highest growth rate that a firm can maintain without changing its capital structure. It is a more reliable measure of growth for all variables derived from the financial statements.

\subsection{The Sustainable Growth Rate}

The sustainable growth rate is defined as the firm's rate of dividend and earnings growth that can be sustained for a given level of return on equity assuming a constant capital structure. It is calculated from:

$$
g_{0}=b_{0} \times R O E_{0}
$$

Where: $g_{0}$ is the firm's current sustainable growth rate; $R O E_{0}$ is the current return on equity and $b_{0}$ is the current earnings retention rate which is calculated as: $b_{0}=1-$ Dividend payout ratio.

This study used the sustainable growth rates as a proxy for growth in all the variables.

\subsection{The Dividend Valuation Models}

The dividend valuation models include the Gordon-Shapiro Dividend constant growth dividend discount model and its variant derived by Parrino (2005). The models, which assume a constant perpetual growth in dividends, are derived from the basic dividend valuation model which states that the current intrinsic value of a share is equal to the present value of expected dividends. The investors' required rate of return, which is the firm's cost of equity is used as the discount rate. 


\subsubsection{The Constant Growth Dividend Discount Model}

The constant growth dividend discount model which is also called the Gordon Dividend Valuation or the GordonShapiro Dividend Valuation model after Gordon and Shapiro (1956) and Gordon (1962) is formally stated as:

$$
P_{0}=\frac{D P S_{0}(1+g)}{\left(k_{e}-g\right)} \equiv \frac{D P S_{1}}{\left(k_{e}-g\right)}
$$

Where

$$
D P S_{1}=D P S_{0} \times(1+g)
$$

The cost of equity can then be calculated from:

$$
k_{e}=\frac{D P S_{0}(1+g)}{P_{0}}+g \equiv \frac{D P S_{1}}{P_{0}}+g
$$

This model assumes indefinite constant growth in dividends. It simply states that the cost of equity is equal to the forward dividend yield plus the dividend growth rate in perpetuity.

\subsubsection{The Alternative Constant Growth Dividend Discount Model}

Parrino (2005, p. 23) presents a modified dividend discount model that uses the earnings per share (EPS) and pay-out ratio instead of the dividends. The firm's current dividend per share, $D P S_{0}$, is given by:

$$
D P S_{0}=E P S_{0} \times\left(1-b_{0}\right)
$$

Where $E P S_{0}$ is current earnings per share and $\left(1-b_{0}\right)$ is the dividend pay-out ratio $\left(\left(1-b_{0}\right)=\frac{D_{0}}{E P S_{0}}\right)$ Substituting for $D_{0}$ in model 9 , the constant growth dividend discount model, yields:

$$
P_{0}=\frac{E P S_{0}(1+g) \times\left(1-b_{0}\right)}{\left(k_{e}-g\right)} \equiv \frac{E P S_{1} \times\left(1-b_{0}\right)}{\left(k_{e}-g\right)}
$$

The cost of equity is then calculated from:

$$
k_{e}=\left(1-b_{0}\right) \times \frac{E P S_{0}(1+g)}{P_{0}}+g \equiv\left(1-b_{0}\right) \times \frac{E P S_{1}}{P_{0}}+g
$$

In theory, this model is equivalent to the Gordon-Shapiro constant growth model.

\subsection{Market Multiples Models}

The traditional market multiples models use the market multiple of a comparable firm to estimate the share value of the target firm. The main drawback of this valuation approach is that a variable of another firm is used to value the equity of another firms and this is problematic as firms differ in financial performance, risk profiles, operational efficiencies, management efficiency and effectiveness, future prospects and size. The heterogeneity in these variables across firms make it extremely difficult to find a firm that exactly match the profile of the target firm in all aspects. To resolve this dilemma, a number of researchers notably Damodaran (2006), Pinto, Henry, Robinson and Stowe (2010) and Suozzo, Cooper, Sutherland and Deng (2001) have developed modern market multiples models that use the target firm's financial data instead. These market multiples models use the firm's cost of equity, sustainable growth rate and other variables such as the firm's earnings per share (EPS), book value per share (BVS) and return on equity (ROE). Given the target firm's current share price, these models can be used to infer the firm's cost of equity. The widely used market multiples in equity valuation are the price-to-earnings and the price-to-book value multiples. 


\subsubsection{Price Earnings Models}

According to Damodaran (2006, p. 266) and Pinto et al. (2010, p. 275), the leading P/E valuation model is obtained by dividing the basic dividend discount model 9 by the firm's leading EPS, $\left(E P S_{1}\right)$ :

$$
\frac{P_{0}}{E P S_{1}}=P E_{0}=\frac{\frac{D P S_{0}(1+g)}{E P S_{1}}}{\left(k_{e}-g\right)} \equiv \frac{\frac{D P S_{1}}{E P S_{1}}}{\left(k_{e}-g\right)}
$$

The ratio $\frac{D P S_{1}}{E P S_{1}}$ gives the firm's pay-out ratio, $\left(1-b_{0}\right)$ where $b$ is the firm's retention rate. The equation can then be simplified to:

$$
\frac{P_{0}}{E P S_{1}}=P E_{1}=\frac{\left(1-b_{0}\right)}{\left(k_{e}-g\right)}
$$

The cost of equity is then calculated as:

$$
k_{e}=\left(1-b_{0}\right) \times \frac{E P S_{0}(1+g)}{P_{0}}+g \equiv g+\frac{\left(1-b_{0}\right) \times E P S_{1}}{P_{0}}
$$

This model is equivalent to Parrino's (2005) model 13.

Suozzo et al. (2001) on the other hand, derived an alternative P/E ratio that uses the firm's ROE and EPS. The firm's sustainable growth rate is given by:

$$
g=b_{0} \times R O E_{0} \Rightarrow b_{0}=\frac{g}{R O E_{0}}
$$

The leading P/E ratio is obtained by substituting $b_{0}=\frac{g}{R O E_{0}}$ into model 15 yields:

$$
\frac{P_{0}}{E P S_{1}}=\frac{\left(1-\frac{g}{R O E_{0}}\right)}{\left(k_{e}-g\right)}
$$

This simplifies to:

$$
\frac{P_{0}}{E P S_{1}}=\frac{R O E_{0}-g}{R O E_{0} \times\left(k_{e}-g\right)}
$$

The cost of equity is then calculated as:

$$
k_{e}=g+\frac{R O E_{0}-g}{R O E_{0} \times P_{0}} \times E P S_{0} \times(1+g) \equiv g+\frac{R O E_{0}-g}{R O E_{0} \times P_{0}} \times E P S_{1}
$$

\subsubsection{The Price-to-Book (P/BV) Value of Equity Ratio}

This multiple uses the book value of equity which is defined as the current share price scaled up by the book value of equity. From model 15, the current share price, $P_{0}$, is given by:

$$
P_{0}=\frac{\left(1-b_{0}\right) \times E P S_{1}}{\left(k_{e^{-}} g\right)}
$$


According to Damodaran (2006, p. 266), the firm's leading P/BVS ratio is obtained by dividing model 21 by the leading book value per share, $B V S_{1}$ :

$$
\frac{P_{0}}{B V S_{1}}=P B V S_{1}=\frac{\frac{E P S_{1} \times\left(1-b_{0}\right)}{B V S_{1}}}{\left(k_{e}-g\right)}
$$

The factor $E P S_{1} / B V S_{1}$ defines the firm's $R O E_{1}$. Since growth in $E P S_{0}$ is equal to growth in $B V S_{0}$, it follows that:

$$
\frac{E P S_{0} \times(1+g)}{B V S_{0} \times(1+g)}=\frac{E P S_{1}}{B V S_{1}}
$$

Thus:

$$
\frac{E P S_{0}}{B V S_{0}}=\frac{E P S_{1}}{B V S_{1}}=R O E_{1}=R O E_{0}
$$

This therefore implies that the leading P/BVS ratio is therefore given by:

$$
\frac{P_{0}}{B V S_{1}}=P / B V S_{1}=\frac{R O E_{0} \times\left(1-b_{0}\right)}{\left(k_{e}-g\right)}
$$

The cost of equity is then calculated as:

$$
k_{e}=g+\frac{R O E_{1} \times\left(1-b_{0}\right)}{P_{0}} \times B V S_{0} \times(1+g) \equiv g+\frac{R O E_{1} \times\left(1-b_{0}\right)}{P_{0}} \times B V S_{1}
$$

Suozzo et al. (2001) derive an alternative P/BV model. The firm's sustainable growth rate is given by: $g=$ $b_{0} \times R O E_{0} \Rightarrow b_{0}=g / R O E_{0}$. Substituting for $b$ in model 23 gives:

$$
\frac{P_{0}}{B V S_{1}}=P B V_{1}=\frac{R O E_{1} \times\left(1-\frac{g}{R O E_{1}}\right)}{\left(k_{e}-g\right)}
$$

This simplifies to:

$$
\frac{P_{0}}{B V S_{1}}=P B V_{1}=\frac{R O E_{1}-g}{\left(k_{e}-g\right)}
$$

The cost of equity is given by:

$$
k_{e}=g+\frac{R O E_{0}-g}{P_{0}} \times B V S_{0} \times(1+g) \equiv g+\frac{R O E_{0}-g}{P_{0}} \times B V S_{1}
$$

\subsection{The Residual Income Valuation Model}

The residual income valuation model, which is derived from the dividend discount model, was firstly introduced by Edwards and Bell (1961) in their paper- The theory and measurement of business income. The model was further developed Peasnell (1982), Ohlson (1995) and Feltham and Ohlson (1995). Residual income is simply defined as net income less capital charge of generating the income. According to Frankel and Lee (1998), Gebhardt, Lee and Swaminathan (2001) and Hirst and Hopkins (2000, p. 17) and Pinto et al. (2010, p. 223), the Ohlson (1995) and Feltham and Ohlson (1995) residual model can also be stated in terms of the firm's return on equity (ROE). That is:

$$
P_{0}=B V S_{1}+\left(\frac{R O E_{0}-k_{e}}{k_{e}-g}\right) \times B V S_{1}
$$


Solving for $k_{e}$ and simplifying yields the model:

$$
k_{e}=g+\frac{B V S_{0} \times(1+g) \times\left(R O E_{0}-g\right)}{P_{0}} \equiv g+\frac{B V S_{1}\left(R O E_{0}-g\right)}{P_{0}}
$$

\subsection{The OhIson and Juettner-Nauroth (2005) (OJ) Model}

According to the Ohlson and Juettner-Nauroth (2005) (OJ) model, equity value consists of two components:

1. Capitalised next period earnings and,

2. The present values of all future abnormal earnings growth which are defined as the capitalised expected changes in earnings adjusted for dividends. They term these earnings the abnormal earnings growth.

The model allows for the relaxation of the clean surplus assumptions. Model assumes economy-wide growth rates after the two year forecast period. Gode and Mohanram (2003, p. 403) state the model as:

$$
\mathrm{P}_{0}=\frac{E P S_{1}}{k_{e}}+\frac{\left(E P S_{2}-E P S_{1}-k_{e}\left(E P S_{1}-D P S_{1}\right)\right)}{k_{e}\left(k_{e}-g\right)}
$$

Solving for the cost of equity, $k_{e}$, gives the quadratic solution:

$$
k_{e}=\frac{\left(\mathrm{P}_{0} \times g+D P S_{1}\right) \pm \sqrt{\left(\mathrm{P}_{0} \times g+D P S_{1}\right)^{2}-4 \times \mathrm{P}_{0} \times\left(E P S_{1} \times g-E P S_{2}+E P S_{1}\right)}}{2 \times P_{0}}
$$

This simplifies to:

$$
k_{e}=\frac{\left(\mathrm{P}_{0} \times g+D P S_{1}\right)+\sqrt{\left(\mathrm{P}_{0} \times g+D P S_{1}\right)^{2}-4 \times \mathrm{P}_{0} \times\left(E P S_{1} \times g-E P S_{2}+E P S_{1}\right)}}{2 \times P_{0}}
$$

\section{APPLYING THE MODELS}

The final models that were tested are summarised as follows:

Model 1: The capital asset pricing model (CAPM):

$$
k_{e}=r_{f}+\beta_{i, m}\left[E\left(r_{m}\right)-E\left(r_{f}\right)\right]
$$

Model 2: The constant growth dividend discount model:

$$
k_{e}=\frac{D P S_{0}(1+g)}{P_{0}}+g \equiv \frac{D P S_{1}}{P_{0}}+g
$$

Model 3: The Parrino (2005) alternative constant growth dividend discount model and the P/E multiple model:

$$
k_{e}=\left(1-b_{0}\right) \times \frac{E P S_{1}}{P_{0}}+g \equiv\left(1-b_{0}\right) \times \frac{E P S_{0}(1+g)}{P_{0}}+g
$$

Model 4: The Suozzo et al (2001) P/E multiple model:

$$
k_{e}=g+\frac{R O E_{0}-g}{R O E_{0} \times P_{0}} \times E P S_{0} \times(1+g) \equiv g+\frac{R O E_{0}-g}{R O E_{0} \times P_{0}} \times E P S_{1}
$$


Model 5: The P/B multiple model:

$$
k_{e}=g+\frac{R O E_{0} \times\left(1-b_{0}\right)}{P_{0}} \times B V S_{0} \times(1+g) \equiv g+\frac{R O E_{0} \times\left(1-b_{0}\right)}{P_{0}} \times B V S_{1}
$$

Model 6: The Suozzo et al (2001) P/B multiple model:

$$
k_{e}=g+\frac{R O E_{0}-g}{P_{0}} \times B V S_{0} \times(1+g) \equiv g+\frac{R O E_{0}-g}{P_{0}} \times B V S_{1}
$$

Model 7: The residual income model:

$$
k_{e}=g+\frac{B V S_{0} \times(1+g) \times\left(R O E_{0}-g\right)}{P_{0}} \equiv g+\frac{B V S_{1}\left(R O E_{0}-g\right)}{P_{0}}
$$

Model 8: The OJ (2005) AEG model:

$$
k_{e}=\frac{\left(\mathrm{P}_{0} \times g+D P S_{1}\right)+\sqrt{\left(\mathrm{P}_{0} \times g+D P S_{1}\right)^{2}-4 \times \mathrm{P}_{0} \times\left(E P S_{1} \times g-E P S_{2}+E P S_{1}\right)}}{2 \times P_{0}}
$$

\section{DATA}

The models were used to estimate the cost of equity for the four leading retail JSE-listed firms. The firms used in the study were Lewis Limited, Mr Price Limited, Shoprite Limited and the Foschini Group Limited. These are all mature retail firms which are expected to have stable DPS, ROE, EPS and BVS. To eliminate the earnings distortions that may have arisen as a result of the 2007-2008 global financial crisis, the study used data for the years 2010 to 2014 . All the accounting data used in the study was obtained from the McGregorBFA database. The equity betas and share prices were all obtained from The Financial Times of London database. These were downloaded on the $25^{\text {th }}$ November 2014. The study used the R186 government bond as a proxy for the risk-free rate. The bond matures on 21 December 2026. Its MTM was $7.77 \%$ on the $25^{\text {th }}$ November 2014. The South African market risk premium was obtained from the Damodaran (2006) website. It is currently $7.40 \%$ and $8.44 \%$ when estimated using the Moody's currency and CDS ratings respectively. The study used $7.40 \%$.

\subsection{Hypothesis}

H1: If these models are relevant, they should yield consistent estimates of the firms' cost of equity.

\section{RESULTS}

The summary results of all the models are contained in Table 1.0. The data and calculation details for each model are contained in Annexure 1. Although these firms are expected to be peers, their ROE, EPS, BVS, sustainable growth rates, share prices and costs of equity differ significantly. In all cases, except for Shoprite Ltd.'s estimate using the constant growth dividend valuation model, the cost of equity estimates of all models are lower than those of the CAPM. For all firms, the constant growth dividend discount model that used the firms' sustainable growth as estimated growth for dividends and the AEG model yielded similar estimates for the cost of equity and these have the minimum percentage variance from the CAPM estimates. The variants of the P/E market multiples models yielded similar results. The P/BVS market multiples variants and the residual income models also yielded similar estimates for the cost of equity.

The mean variance of the models' estimates from the CAPM are $-5.91 \%$ and $-6.04 \%$ for Lewis Ltd and The Foschini Group Ltd respectively. The estimates for these firms are closer to those of the CAPM. The estimates for Mr Price and Shoprite however show much higher variance of $-65.30 \%$ and $-37.11 \%$ respectively. In the case of Mr Price Ltd, the high variance may be due to the high estimate for the dividend and firm's sustainable growth rates which are calculated at $24.05 \%$ and $19.73 \%$ respectively. For Shoprite Ltd, the CAPM's very low estimate of $9.56 \%$ for the cost of equity is suspect as it is very close to the current risk-free rate of $7.77 \%$. This low estimate of the cost of equity is 
due to the firm's low beta of 0.2413 . In summary, the estimates given by the models differ from those of the CAPM. The results are mixed with two firms having estimates that are closer to those of the CAPM.

The Table shows the models' estimated cost of equity for the four firms. The input data is contained in Annexure 1. $\mathrm{k}_{\mathrm{e}}$ is the cost of equity estimated using a the specific model and \% Var. is the models' variance from the cost of equity calculated using the CAPM. It is calculated as:

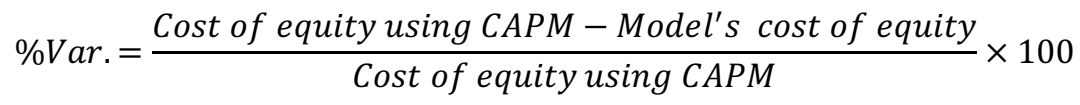

Table 1.0. The cost of equity summary results

\begin{tabular}{|c|c|c|c|c|c|c|c|c|}
\hline & \multicolumn{2}{|c|}{ Lewis Ltd } & \multicolumn{2}{|c|}{ Mr Price Ltd } & \multicolumn{2}{|c|}{ Shoprite Ltd } & \multicolumn{2}{|c|}{ The Foschini Ltd } \\
\hline & $\mathbf{k}_{\mathrm{e}}$ & $\%$ Var. & $\mathbf{k}_{\mathrm{e}}$ & $\%$ Var. & $\mathbf{k}_{\mathrm{e}}$ & $\%$ Var. & $\mathbf{k}_{\mathrm{e}}$ & $\%$ Var. \\
\hline The CAPM Model & $13.21 \%$ & $0.00 \%$ & $13.31 \%$ & $0.00 \%$ & $9.56 \%$ & $0.00 \%$ & $14.61 \%$ & $0.00 \%$ \\
\hline \multicolumn{9}{|c|}{ Income Models Using Sustainable Growth Rate } \\
\hline Dividend discount model & $13.31 \%$ & $(0.77 \%)$ & $21.83 \%$ & $(63.94 \%)$ & $12.87 \%$ & $(34.71 \%)$ & $15.24 \%$ & $(4.31 \%)$ \\
\hline Parrino DDM model & $14.14 \%$ & $(7.04 \%)$ & $22.03 \%$ & $(65.42 \%)$ & $13.20 \%$ & $(38.09 \%)$ & $15.59 \%$ & $(6.70 \%)$ \\
\hline $\begin{array}{l}\text { Suozzo et al (2001) P/E } \\
\text { multiple model }\end{array}$ & $14.14 \%$ & $(7.04 \%)$ & $22.03 \%$ & $(65.42 \%)$ & $13.20 \%$ & $(38.09 \%)$ & $15.59 \%$ & $(6.70 \%)$ \\
\hline $\begin{array}{l}\mathrm{P} / \mathrm{B} \text { multiple } \\
\text { model }\end{array}$ & $14.34 \%$ & $(8.58 \%)$ & $22.12 \%$ & $(66.1$ & $13.19 \%$ & $(38.0$ & $15.60 \%$ & $(6.75 \%)$ \\
\hline $\begin{array}{l}\text { Suozzo et al (2001) P/B } \\
\text { multiple model }\end{array}$ & $14.34 \%$ & $(8$ & 22. & $(66$ & 13 & $3.06 \%)$ & $15.60 \%$ & $(6.7$ \\
\hline Residual income model & $14.34 \%$ & $(8.58 \%)$ & $22.12 \%$ & $(66.12 \%)$ & $13.19 \%$ & $(38.06 \%)$ & $15.60 \%$ & $(6.75 \%)$ \\
\hline OJ (2005) AEG model & $13.31 \%$ & $(0.77 \%)$ & $21.83 \%$ & $(63.94 \%)$ & $12.87 \%$ & $(34.71 \%)$ & $15.24 \%$ & $(4.31 \%)$ \\
\hline Average & $13.99 \%$ & $(5.91 \%)$ & $22.01 \%$ & $(65.30 \%)$ & $13.10 \%$ & (37.11\%) & $15.49 \%$ & $(6.04 \%)$ \\
\hline
\end{tabular}

\section{CONCLUSION}

The aim of this paper was to compare the estimates of the cost of equity for four mature retail firms listed on the Johannesburg Stock Exchange (JSE) calculated using the CAPM and the variants of other leading equity valuation models. The study found that the constant growth dividend discount valuation and the OJ (2005) AEG models give similar estimates which are closer to those of the CAPM. As expected, the P/E market multiples variants yield similar estimates. The residual income model gives estimates that are equal to those of the $\mathrm{P} / \mathrm{B}$ market multiples variants. The models' estimates for Lewis Ltd and The Foschini Group Ltd are closer to the CAPM estimates than those of Mr Price and Shoprite Ltd. The high sustainable growth rate of Mr Price and the low beta for Shoprite may explain the high variance of the models' estimates from the CAPM. This study is however very limited as it only used four firms to test for the equivalence of the models. Future studies may extend this study by using a larger samples to test for the equivalence of these models.

\section{AUTHOR BIOGRAPHIES}

Vusani Moyo, (PhD, MBA, MSc, BA (Hons), ACA (ICAEW), FCMA (CIMA), FCCA (ACCA), is an Associate Professor at the University of Venda, South Africa. He obtained his PhD (Financial Management Sciences), an MSc (Finance) and MBA (Finance) from the University of Pretoria, University of Leicester School of Management and the University of Manchester Business School respectively. His current research interests are capital structure of African financial and non-financial firms, cash flow sensitivity of cash, investment cash flow sensitivity of cash, cost of capital, firm valuation and dividend policy.

Fidelis Mache, (MSc Finance and Investment, ACIS), is a Senior Lecturer at the University of Venda, South Africa. He obtained his MSc (Finance and Investment) from the National University of Science and Technology. His current research interests are in finance particularly in capital structure, private equity funds, cash flow sensitivity of cash, investment cash flow sensitivity of cash, cost of capital, firm valuation and dividend policy. 


\section{REFERENCES}

Bancel, F., \& Mittoo, U. R. (2014). The gap between theory and practice of firm valuation: Survey of European valuation experts. SSRN Electronic Journal. Doi: 10.2139/ssrn.2420380

Brealey, R. A., Myers, S. C. \& Allen, F. (2008). Principles of corporate finance. $9^{\text {th }}$ ed. New York: McGraw-Hill.

Bruner, R. K., Eads, R., Harris, R. \& Higgins, R. (1998). Best practices in estimating the cost of capital: Survey and synthesis. Financial Practice and Education, 8(1),13-28.

Damodaran, A. (2006). Damodaran on valuation: Security analysis for investment and corporate finance. $2^{\text {nd }}$ ed. Hoboken: John Wiley.

Dempsey, M. (2013). The capital asset pricing model (CAPM): The history of a failed revolutionary idea in finance? Abacus, 49 (Supplement): 7-23.

Edwards, E. \& Bell, P. (1961). The theory and measurement of business income. Berkeley: Univ. of California P.

Fama, E. F. \& French, K. R. (1996). Multifactor explanations of asset pricing anomalies. The Journal of Finance, 51(1).

Feltham, G. A. \& Ohlson, J. A. (1995). Valuation and clean surplus accounting for operating and financial activities. Contemporary Accounting Research, 11(4),698-731.

Frankel, R. \& Lee, C. M. C. (1998). Accounting valuation, market expectation, and cross-sectional stock returns. Journal of Accounting and Economics, 25, 283-319.

Gebhardt, W. R., Lee, C. M. C. \& Swaminathan, B. (2001). Toward an implied cost of capital. Journal of Accounting Research, 39(1), 135-176.

Gode, D. \& Mohanram, P. (2003). Infering the cost of capital using the Ohlson-Juettner model. Review of Accounting Studies, 8, 399-431.

Gordon, M. J. (1962). The investment, financing, and valuation of the corporation. Homewood, IL: Richard D. Irwin.

Gordon, M. J. \& Shapiro, E. (1956). Capital equipment analysis: The required rate of profit. Management Science, 3(1),102-110.

Graham, J. R. \& Harvey, C. R. (2001). The theory and practice of corporate finance: Evidence from the field. Journal of Financial Economics, 60(2-3), 187-243.

Hirst, D. E. \& Hopkins, P. E. (2000). Earnings: measurement, disclosure, and the impact on equity valuation. Charlottesville, VA: Research Foundation of AIMR AND Blackwell Series in Finance.

Lintner, J. (1965). The valuation of risk assets and the selection of risky investments in stock portfolio and capital budgets. Review of Economics and Statistics, 47(1),13-37.

Mossin, J. (1966). Equilibrium in capital asset market. Econometrica, 34(4),768-783.

Ohlson, J. A. (1995.) Earnings, book values, and dividends in equity valuation. Contemporary Accounting Research, 11(2),661687.

Ohlson, J. A. \& Juettner-Nauroth, B. E. (2005). Expected EPS and EPS growth as determinants of value. Review of Accounting Studies, 10, 349-365.

Parrino, R. (2005). Proceedings of CFA Institute Conference Proceedings: Choosing the right valuation approach. p. 15-28.

Peasnell, K. V. (1982). Some formal connections between economic values and yields and accounting numbers. Journal of Business Finance and Accounting, 9(3), 361-381.

Pinto, J. E. Henry, E. Robinson, T. R. \& Stowe, J. D. (2010). Equity Asset Valuation, $2^{\text {nd }}$ ed. Hoboken, New Jersey: John Wiley \& Sons, Inc.

Sharpe, W. F. (1962). Capital asset prices: a theory of market equilibrium under conditions of risk. The Journal of Finance, $19(3), 425-442$.

Sharpe, W. F. (1964). Capital assets prices: A theory of market equilibrium under conditions of risk. Journal of Finance, 19,425 442.

Suozzo, P., Cooper, S., Sutherland, G. \& Deng, Z. (2001). Valuation multiples: A primer. UBS Warburg Global Equity Research, Valuation Primer Series, 1, 1-46.

Treynor, J. L. (1962). Toward a theory of market value of risky assets. Unpublished Manuscript. Cited but unavailable.

Welch, I. (2008). The consensus estimate for the equity premium by academic financial economists in December 2007. Unpublished Working Paper, Brown University. [Online] Available from: http://papers.ssrn.com/sol3/papers.cfm?abstract_id=1084918. [Downloaded: 2014-11-12]. 


\section{ANNEXURE 1}

The firms' sustainable growth rates are given below. These are calculated as:

$$
g_{0}=R O E_{0} \times b_{0}
$$

Where: $g_{0}$ is the firm's sustainable growth; $R O E$ return on equity and $b$ is the earnings retention rate which is calculated as:

$$
b_{0}=1-\text { Dividend payout ratio }
$$

Table 2.0. Estimating the Firms' Sustainable Growth Rates

\begin{tabular}{l|c|c|c|c}
\hline & Lewis & Mr Price & Shoprite & The Foschini \\
\hline Dividend pay-out ratio (\%) & $54.19 \%$ & $58.57 \%$ & $49.65 \%$ & $54.93 \%$ \\
\hline Retention rate (\%) & $45.81 \%$ & $41.43 \%$ & $50.35 \%$ & $45.07 \%$ \\
\hline Current ROE (\%) & $15.77 \%$ & $47.62 \%$ & $21.66 \%$ & $25.73 \%$ \\
\hline Sustainable growth rate\% & $\mathbf{7 . 2 2} \%$ & $\mathbf{1 9 . 7 3 \%}$ & $\mathbf{1 0 . 9 1 \%}$ & $\mathbf{1 1 . 6 0 \%}$ \\
\hline
\end{tabular}

\section{ESTIMATING THE COST OF EQUITY}

The capital asset pricing model (CAPM) of William Sharpe (1962) and John Lintner (1965) is stated as:

$$
\begin{aligned}
& k_{e}=r_{f}+\beta_{i, m}\left[E\left(r_{m}\right)-E\left(r_{f}\right)\right] \\
& \text { Equity market risk premium }=\left[E\left(r_{m}\right)-E\left(r_{f}\right)\right] \\
& \text { Equity risk premium }=\beta_{i, m}\left[E\left(r_{m}\right)-E\left(r_{f}\right)\right]
\end{aligned}
$$

Table 3.0. Estimating the Cost of Equity Using the Capital Asset Pricing Model

\begin{tabular}{l|c|c|c|c}
\hline & Lewis & Mr Price & Shoprite & The Foschini \\
\hline Risk-free rate (\%) & $7.77 \%$ & $7.77 \%$ & $7.77 \%$ & $7.77 \%$ \\
\hline Average market return (\%) & $15.17 \%$ & $15.17 \%$ & $15.17 \%$ & $15.17 \%$ \\
\hline Equity market risk premium (\%) & $7.40 \%$ & $7.40 \%$ & $7.40 \%$ & $7.40 \%$ \\
\hline Beta & 0.7352 & 0.7493 & 0.2413 & 0.9245 \\
\hline Equity Risk premium (\%) & $5.44 \%$ & $5.54 \%$ & $1.79 \%$ & $6.84 \%$ \\
\hline Cost of equity & $\mathbf{1 3 . 2 1 \%}$ & $\mathbf{1 3 . 3 1 \%}$ & $\mathbf{9 . 5 6 \%}$ & $\mathbf{1 4 . 6 1 \%}$ \\
\hline
\end{tabular}

The constant growth dividend discount model:

$$
\begin{aligned}
& k_{e}=\frac{D_{0}(1+g)}{P_{0}}+g \equiv \frac{D_{1}}{P_{0}}+g \\
& D P S_{1}=D P S_{0} \times(1+g
\end{aligned}
$$

Table 3.1. Estimating the Cost of Equity Using the Constant Growth Dividend Discount Model

\begin{tabular}{l|c|c|c|c}
\hline & Lewis & Mr Price & Shoprite & The Foschini \\
\hline Current share price (cents) & 7739.00 & 23363.00 & 16778.00 & 13949.00 \\
\hline Current dividend paid (cents) & 439.45 & 409.70 & 297.50 & 455.60 \\
\hline Sustainable growth rate (SGR) \% & $7.22 \%$ & $19.73 \%$ & $10.91 \%$ & $11.60 \%$ \\
\hline Cost of equity: SGR & $\mathbf{1 3 . 3 1 \%}$ & $\mathbf{2 1 . 8 3 \%}$ & $\mathbf{1 2 . 8 7 \%}$ & $\mathbf{1 5 . 2 4 \%}$ \\
\hline
\end{tabular}


The Parrino (2005) alternative constant growth dividend discount model and the P/E multiple model:

$$
\begin{aligned}
& k_{e}=(1-b) \times \frac{E P S_{1}}{P_{0}}+g \equiv(1-b) \times \frac{E P S_{0}(1+g)}{P_{0}}+g \\
& E P S_{1}=E P S_{0} \times(1+g
\end{aligned}
$$

Table 3.2. Estimating the Cost of Equity Using the Parrino (2005) Alternative to the Constant Growth Dividend Discount and the P/E Multiple Model

\begin{tabular}{l|c|c|c|c}
\hline & Lewis & Mr Price & Shoprite & The Foschini \\
\hline Current share price (cents) & 7739.00 & 23363.00 & 16778.00 & 13949.00 \\
\hline Current EPS (cents) & 921.10 & 765.10 & 697.60 & 908.90 \\
\hline Dividend pay-out ratio (\%) & $54.19 \%$ & $58.57 \%$ & $49.65 \%$ & $54.93 \%$ \\
\hline Sustainable growth rate (SGR) \% & $7.22 \%$ & $19.73 \%$ & $10.91 \%$ & $11.60 \%$ \\
\hline Cost of equity: SGR & $\mathbf{1 4 . 1 4 \%}$ & $\mathbf{2 2 . 0 3 \%}$ & $\mathbf{1 3 . 2 0} \%$ & $\mathbf{1 5 . 5 9 \%}$ \\
\hline
\end{tabular}

The Suozzo et al. (2001) P/E multiple model:

$$
\begin{aligned}
& k_{e}=g+\frac{R O E_{0}-g}{R O E_{0} \times P_{0}} \times E P S_{0} \times(1+g) \equiv g+\frac{R O E_{0}-g}{R O E_{0} \times P_{0}} \times E P S_{1} \\
& E P S_{1}=E P S_{0} \times(1+g)
\end{aligned}
$$

Table 3.3. Estimating the Cost of Equity Using the Suozzo et al (2001) P/E Market Multiples Model

\begin{tabular}{l|c|c|c|c}
\hline & Lewis & Mr Price & Shoprite & The Foschini \\
\hline Current share price (cents) & 7739.00 & 23363.00 & 16778.00 & 13949.00 \\
\hline Current EPS (cents) & 921.10 & 765.10 & 697.60 & 908.90 \\
\hline Current ROE (\%) & $15.77 \%$ & $47.62 \%$ & $21.66 \%$ & $25.73 \%$ \\
\hline Sustainable growth rate (SGR) \% & $7.22 \%$ & $19.73 \%$ & $10.91 \%$ & $11.60 \%$ \\
\hline Cost of equity: SGR & $\mathbf{1 4 . 1 4 \%}$ & $\mathbf{2 2 . 0 3 \%}$ & $\mathbf{1 3 . 2 0} \%$ & $\mathbf{1 5 . 5 9 \%}$ \\
\hline
\end{tabular}

The P/B multiple model:

$$
\begin{aligned}
& k_{e}=g+\frac{R O E_{0} \times(1-b)}{P_{0}} \times B V S_{1} \\
& B V S_{1}=B V S_{0} \times(1+g
\end{aligned}
$$

Table 3.4. Estimating the Cost of Equity Using the P/B Market Multiples Model

\begin{tabular}{|l|c|c|c|c}
\hline & Lewis & Mr Price & Shoprite & The Foschini \\
\hline Current ROE (\%) & $15.77 \%$ & $47.62 \%$ & $21.66 \%$ & $25.73 \%$ \\
\hline Sustainable growth rate (SGR) \% & $7.22 \%$ & $19.73 \%$ & $10.91 \%$ & $11.60 \%$ \\
\hline Dividend pay-out ratio (\%) & $54.19 \%$ & $58.57 \%$ & $49.65 \%$ & $54.93 \%$ \\
\hline Current BVS (cents) & 6012.76 & 1671.99 & 3217.27 & 3539.04 \\
\hline Current share price (cents) & 7739.00 & 23363.00 & 16778.00 & 13949.00 \\
\hline Cost of equity: SGR & $\mathbf{1 4 . 3 4 \%}$ & $\mathbf{2 2 . 1 2 \%}$ & $\mathbf{1 3 . 1 9 \%}$ & $\mathbf{1 5 . 6 0 \%}$ \\
\hline
\end{tabular}


The Suozzo et al (2001) P/B multiple model:

$$
\begin{aligned}
& k_{e}=g+\frac{R O E_{0}-g}{P_{0}} \times B V S_{0} \times(1+g) \equiv g+\frac{R O E_{0}-g}{P_{0}} \times B V S_{1} \\
& B V S_{1}=B V S_{0} \times(1+g
\end{aligned}
$$

Table 3.5. Estimating the Cost of Equity Using the Suozzo et al (2001) P/B Market Multiples Model

\begin{tabular}{l|c|c|c|c}
\hline & Lewis & Mr Price & Shoprite & The Foschini \\
\hline Current share price (cents) & 7739.00 & 23363.00 & 16778.00 & 13949.00 \\
\hline Current BVS (cents) & 6012.76 & 1671.99 & 3217.27 & 3539.04 \\
\hline Current ROE (\%) & $15.77 \%$ & $47.62 \%$ & $21.66 \%$ & $25.73 \%$ \\
\hline Sustainable growth rate (SGR) \% & $7.22 \%$ & $19.73 \%$ & $10.91 \%$ & $11.60 \%$ \\
\hline Cost of equity: SGR & $\mathbf{1 4 . 3 4 \%}$ & $\mathbf{2 2 . 1 2 \%}$ & $\mathbf{1 3 . 1 9 \%}$ & $\mathbf{1 5 . 6 0 \%}$ \\
\hline
\end{tabular}

The residual income model:

$$
\begin{aligned}
& k_{e}=g+\frac{B V S_{0} \times(1+g) \times\left(R O E_{0}-g\right)}{P_{0}} \equiv g+\frac{B V S_{1} \times\left(R O E_{0}-g\right)}{P_{0}} \\
& B V S_{1}=B V S_{0} \times(1+g)
\end{aligned}
$$

Table 3.6. Estimating the Cost of Equity Using the Residual Income Model

\begin{tabular}{l|c|c|c|c}
\hline & Lewis & Mr Price & Shoprite & The Foschini \\
\hline Current ROE (\%) & $15.77 \%$ & $47.62 \%$ & $21.66 \%$ & $25.73 \%$ \\
\hline Sustainable growth rate (SGR) \% & $7.22 \%$ & $19.73 \%$ & $10.91 \%$ & $11.60 \%$ \\
\hline Current BVS (cents) & 6012.76 & 1671.99 & 3217.27 & 3539.04 \\
\hline Current share price (cents) & 7739.00 & 23363.00 & 16778.00 & 13949.00 \\
\hline Cost of equity: SGR & $\mathbf{1 4 . 3 4 \%}$ & $\mathbf{2 2 . 1 2 \%}$ & $\mathbf{1 3 . 1 9 \%}$ & $\mathbf{1 5 . 6 0 \%}$ \\
\hline
\end{tabular}

The OJ (2005) AEG model is expressed as:

$$
\begin{aligned}
& k_{e}=\frac{\left(\mathrm{P}_{0} \times g_{p}+D P S_{1}\right)+\sqrt{\left(\mathrm{P}_{0} \times g_{p}+D P S_{1}\right)^{2}-4 \times \mathrm{P}_{0} \times\left(E P S_{1} \times g_{p}-E P S_{2}+E P S_{1}\right)}}{2 \times P_{0}} \\
& D P S_{1} \equiv \text { Dividend per share }_{2015}=\text { Dividend per share }_{2014} \times(1+g) \\
& E P S_{1} \equiv E P S_{2015}=E P S_{2014} \times(1+g) \\
& E P S_{2} \equiv E P S_{2016}=E P S_{2015} \times(1+g) \equiv E P S_{2014} \times(1+g)^{2}
\end{aligned}
$$

Table 3.7. Estimating the Cost of Equity Using the OJ (2005) AEG Model

\begin{tabular}{l|c|c|c|c}
\hline & Lewis & Mr Price & Shoprite & The Foschini \\
\hline Dividend per share (cents): 2014 & 439.45 & 409.70 & 297.50 & 455.60 \\
\hline Dividend per share (cents): 2015 & 471.20 & 490.53 & 329.94 & 508.43 \\
\hline EPS (cents): 2014 & 921.10 & 765.10 & 697.60 & 908.90 \\
\hline EPS (cents): 2015 & 987.64 & 916.05 & 773.68 & 1014.30 \\
\hline EPS (cents): 2016 & 1058.99 & 1096.77 & 858.05 & 1131.92 \\
\hline Current share price (cents) & 7739.00 & 23363.00 & 16778.00 & 13949.00 \\
\hline Sustainable growth rate (SGR) \% & $7.22 \%$ & $19.73 \%$ & $10.91 \%$ & $11.60 \%$ \\
\hline Cost of equity: SGR & $\mathbf{1 3 . 3 1}$ & $\mathbf{2 1 . 8 3 \%}$ & $\mathbf{1 2 . 8 7 \%}$ & $\mathbf{1 5 . 2 4 \%}$ \\
\hline
\end{tabular}




\section{NOTES}

